\title{
Short communication: Increased somatic cell count is associated with milk loss and reduced feed efficiency in lactating dairy cows
}

\author{
T. L. Potter, ${ }^{*}$ † C. Arndt, ${ }^{* 1}$ and A. N. Hristov ${ }^{*} \ddagger$ \\ *Office of Chief Scientist, Environmental Defense Fund, San Francisco, CA 94105 \\ †College of Veterinary Medicine, Cornell University, Ithaca, NY 14853 \\ ‡Department of Animal Science, The Pennsylvania State University, University Park 16802
}

\begin{abstract}
The objective was to evaluate the relationship of somatic cell count (SCC; cells $/ \mathrm{mL}$ ) with milk yield, energy-corrected milk yield (ECM; kg/d), dry matter intake (DMI; $\mathrm{kg} / \mathrm{d}$ ), feed efficiency for milk $\left(\mathrm{FE}_{\mathrm{MY}} ; \mathrm{kg}\right.$ of milk/kg of DMI), and feed efficiency for ECM $\left(\mathrm{FE}_{\mathrm{ECM}}\right.$; $\mathrm{kg}$ of $\mathrm{ECM} / \mathrm{kg}$ of DMI) in lactating dairy cows. We analyzed an SCC database consisting of 7 experiments, which were conducted at The Pennsylvania State University's Dairy Teaching and Research Center between 2009 and 2015. The experiments included in the SCC database were randomized block designs and investigated dietary effects on cow performance over 6 to 11 wk. Each experiment took repeated measurements of SCC, milk yield, milk composition, and DMI. After exclusion of records from cows without lactation number, days in milk, and only 1 measurement, the database comprised 1,094 observations of 254 cows for estimating the effect of SCC on milk yield, DMI, and $\mathrm{FE}_{\mathrm{MY}}$ and 1,079 observations of 250 cows for estimating the

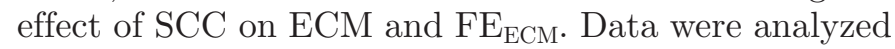
in $\mathrm{R}$ using a linear mixed model with natural logarithm of SCC, lactation number $(1,2$, and $\geq 3)$, days in milk, and the interactions of the linear predictors as fixed effects and cow within block and experiment as random effect. Natural logarithm of SCC was negatively correlated with milk yield, $\mathrm{ECM}, \mathrm{DMI}, \mathrm{FE}_{\mathrm{MY}}$, and $\mathrm{FE}_{\mathrm{ECM}}$. Our results suggest that a cow with relatively high SCC $(250,000$ cells $/ \mathrm{mL})$ compared with a cow with a relatively low SCC $(50,000$ cells $/ \mathrm{mL})$ produces, on average, $1.6 \mathrm{~kg} / \mathrm{d}$ less milk, consumes $0.3 \mathrm{~kg} / \mathrm{d}$ less DMI, produces $0.04 \mathrm{~kg}$ less milk per $\mathrm{kg}$ of DMI, and produces 0.03 less ECM per kg of DMI. The observed decrease of feed efficiency with increased SCC adds to previously
\end{abstract}

Received October 29, 2017.

Accepted June 6, 2018.

${ }^{1}$ Corresponding author: claudia.arndt@catie.ac.cr known economic losses and environmental impacts associated with mastitis, which should provide a further incentive to control mastitis in dairy cows.

Key words: somatic cell count, milk loss, dry matter intake, feed efficiency

\section{Short Communication}

Mastitis is defined as inflammation of the mammary gland due to bacterial infection. It has detrimental effects beyond causing pain and reduced cow welfare (Leslie and Petersson-Wolfe, 2012), including productive losses, increased costs, and reduced returns. Milk losses from mastitis can vary depending on a cow's DIM at the time of infection, previous infections (Cha et al., 2011), parity (Bartlett et al., 1991), and type of pathogen (Cha et al., 2011) and have been observed from as little as $0.24 \mathrm{~kg} / \mathrm{d}$ (Hortet et al., 1999) to as much as $9.68 \mathrm{~kg} / \mathrm{d}$ (Dürr et al., 2008). Whereas cost per case of mastitis can vary by the type of pathogen, Cha et al. (2011) reported that, on average, the economic impact of 1 case can be between $\$ 95$ and $\$ 211$ for costs of treatment, discarded milk, labor, and culturing tests. Rollin et al. (2015) estimated the average case of clinical mastitis resulted in a total economic cost of $\$ 444$ (\$128 in direct costs and $\$ 316$ in indirect costs). Increasing prevalence of mastitis on a farm also has a negative effect on milk quality and may cause producers to lose premiums awarded for high-quality milk.

Clinical mastitis is diagnosed by a sudden onset of udder inflammation and abnormal milk, whereas subclinical mastitis often lacks these signs and can be diagnosed by increased SCC. Feed efficiency $(\mathbf{F E})$ is broadly described as an amount of product per amount of feed input in dairy cattle with units of product varying from kilogram of milk and ECM to body tissue gain (VandeHaar et al., 2016). Maximizing FE is expected to be even more important in the future to continue to feed the rising global population with limited resources (Godfray et al., 2010). In addition, increasing FE provides a higher income over feed cost for the farmer; 
Arndt et al. (2015) reported that cows selected for high FE produced $98 \%$ more milk than cows selected for low FE with only $21 \%$ more DMI.

Feed efficiency is based largely on nutrient partitioning (Bauman et al., 1985), which is affected by the health status of the cow and can cause changes to milk yield and DMI (Ballou, 2012). When an IMI occurs, an immune response is elicited, and, depending on the pathogen, a series of local and systemic effects may occur, including a drop in DMI (Ballou, 2012). Rather than mobilizing energy to make up for the drop in DMI, nutrient partitioning changes and milk production drops (Ballou, 2012). Considering this response to infection as well as the decreased dilution of maintenance due to a lower milk yield (Bauman et al., 1985), mastitis may affect the FE of a cow. We investigated milk production, ECM, DMI, and FE losses associated with increased SCC in dairy cows. We hypothesized that increased SCC not only leads to losses in milk production, but also decreases FE, which would further increase costs of mastitis and, thus, possibly increase the incentives to control mastitis.

We analyzed an SCC database consisting of 7 experiments (Lee et al., 2011, 2012a,b; Giallongo et al., 2015; Hristov et al., 2015; Giallongo et al., 2016, 2017), which were conducted at The Pennsylvania State University's Dairy Teaching and Research Center between 2009 and 2015. The experiments were randomized block designs that investigated dietary effects on cow performance over 6 to $11 \mathrm{wk}$. In each experiment, each cow received only 1 dietary treatment. Measurements included SCC, milk yield, ECM, DMI, FE for milk ( $\mathbf{F E}_{\mathrm{MY}} ; \mathrm{kg}$ of milk/ $\mathrm{kg}$ of DMI), and FE for ECM ( $\mathbf{F E}_{\mathbf{E C M}}$; $\mathrm{kg}$ of ECM $/ \mathrm{kg}$ of DMI). Observations that did not include lactation number, DIM, or at least 2 measurements per cow were excluded, resulting in a database that consisted of 1,094 observations of 254 cows (208 cows were used only in 1 experiment, 42 cows were used in 2 experiments, and 4 cows were used in 3 experiments; Table 1). As milk composition data were not available for all observations, fewer data were used to study the effect of SCC on ECM and $\mathrm{FE}_{\mathrm{ECM}}(1,079$ observations of 250 cows, of which 208 cows were used only in 1 experiment, 39 cows were used in 2 experiments, and 3 cows were used in 3 experiments). Cow within block within experiment was included as random effect because it has been shown that mastitis in 1 lactation can affect milk production in subsequent lactations (Hortet and Seegers, 1998). The statistical analyses were carried out using $\mathrm{R}$ statistical language (version 3.2.1, R Core Team, Vienna, Austria). The lmer function (Bates et al., 2015) was used to analyze the following linear mixed model:

$$
\begin{gathered}
\mathrm{Y}_{\text {hijk }}=\beta_{0}+\beta_{1} \times \operatorname{lnSCC}+\beta_{2} \times \text { lactation }_{\mathrm{h}}+\beta_{3} \\
\times \mathrm{DIM}+\beta_{4} \times \text { lactation }_{\mathrm{h}} \times \mathrm{DIM}+\beta_{5} \times \text { lactation }_{\mathrm{h}} \\
\times \operatorname{lnSCC}+\beta_{6} \times \operatorname{lnSCC} \times \mathrm{DIM}+\beta_{7} \times \text { lactation }_{\mathrm{h}} \\
\times \operatorname{lnSCC} \times \mathrm{DIM}+\operatorname{cow}_{\mathrm{i}}\left[\text { block }_{\mathrm{j}}\left(\exp _{\mathrm{k}}\right)\right]+\mathrm{e}_{\mathrm{hijk}},
\end{gathered}
$$

where $Y_{\text {hijk }}$ is the response variable; $\beta_{0}$ is the overall mean; $\beta_{1}$ is the regression coefficient of the natural logarithm of SCC; lnSCC is the fixed effect of the natural logarithm of SCC; $\beta_{2}$ is the regression coefficient of the hth class of lactation; lactation $\mathrm{h}_{\mathrm{h}}$ is the fixed effect of class $\mathrm{h}$ of lactation ( 3 classes, lactation $=1,2$, and $\geq 3$ ); $\beta_{3}$ is the regression coefficient of DIM; DIM is the fixed effect of the days in milk; $\beta_{4}$ is the regression coefficient of interaction of lactation ${ }_{\mathrm{h}}$ and DIM; $\beta_{5}$ is the regression coefficient of interaction of lactation $_{h}$ and $\operatorname{lnSCC}$; $\beta_{6}$ is the regression coefficient of interaction of $\operatorname{lnSCC}$ and DIM; $\beta_{7}$ is the regression coefficient of interaction of lactation $\mathrm{h}, \operatorname{lnSCC}$, and DIM; $\operatorname{cow}_{\mathrm{i}}\left[\right.$ block $\left._{\mathrm{j}}\left(\exp _{\mathrm{k}}\right)\right]$ is the random effect of cow i (classes, $\mathrm{i}=1$ to 254) within block $\mathrm{j}$ (classes, block $=1$ to 12 ) within experiment $k$ (classes, experiment $=1$ to 7 ); and $\mathrm{e}_{\mathrm{hijk}}$ is the residual error. Backward selection and the likelihood ratio test were used to select the model. The following interaction terms were not retained for all response variables because they were not significant $(P>0.05)$ : lactation $\times$ $\operatorname{lnSCC} \times$ DIM, $\operatorname{lnSCC} \times$ DIM, and lactation $\times \operatorname{lnSCC}$. Furthermore, the interaction of lactation $\times$ DIM was not significant $(P>0.05)$ for $\mathrm{FE}_{\mathrm{MY}}$ and $\mathrm{FE}_{\mathrm{ECM}}$ and, thus, was not retained in the respective models.

In the SCC database, $\operatorname{lnSCC}$ was negatively correlated with milk production, ECM, DMI, $\mathrm{FE}_{\mathrm{MY}}$, and $\mathrm{FE}_{\mathrm{ECM}}$ (Table 2). The 95\% confidence interval of predicted milk yield, ECM, DMI, $\mathrm{FE}_{\mathrm{MY}}$, and $\mathrm{FE}_{\mathrm{ECM}}$ losses for SCC up to 750,000 cells $/ \mathrm{mL}$ based on the SCC database are reported in Table 3. At SCC of 250,000 cells/mL, with referent SCC of $1,7,400,50,000$, and 100,000 cells $/ \mathrm{mL}$, predicted milk loss was 4.5 to $6.2,2.9$ to $4.0,1.3$ to 1.8 , and 1.1 to $1.6 \mathrm{~kg} / \mathrm{d}$, respectively. The predicted milk losses were similar to losses predicted by using the partial regression coefficients reported by Raubertas and Shock (1982) and a referent SCC of 1 cell $/ \mathrm{mL}$. A referent SCC of 1 cell $/ \mathrm{mL}$ was used because the natural logarithm of zero is undefined and Raubertas and Shook (1982) did not report a referent SCC. Furthermore, our predicted losses were similar to losses predicted by Hortet and Seegers (1998), Dürr et al. (2008), and Hand et al. (2012), but not to losses reported by Halasa et al. (2009). At SCC of 250,000 cells/ mL, Raubertas and Shock (1982), Hortet et al. (1999), Dürr et al. (2008), and Hand et al. (2012) predicted 


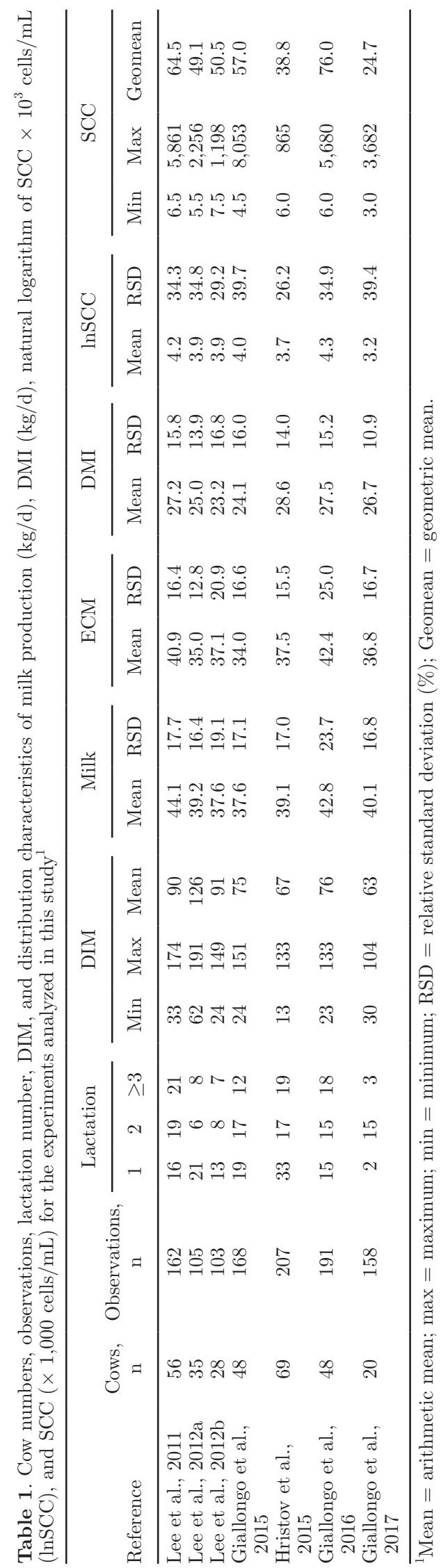

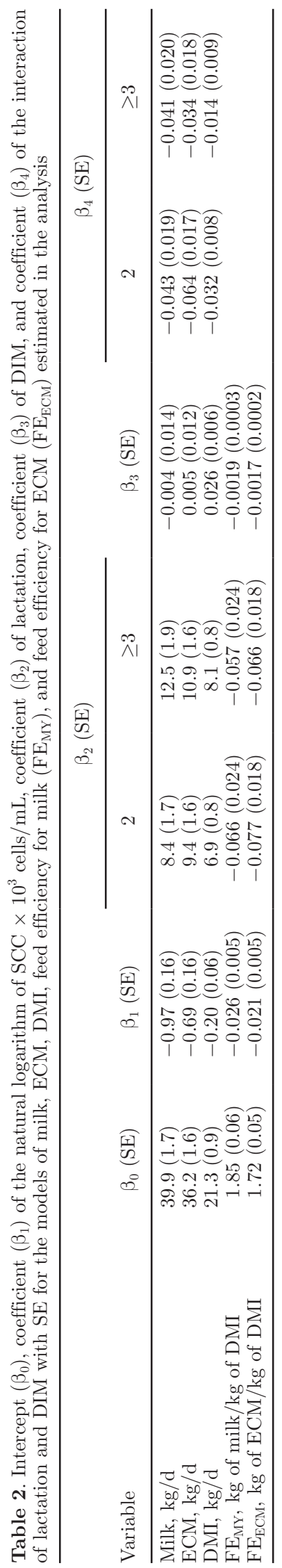


milk loss of 2.4 to $5.1,0.6$ to $2.8,1.2$ to 6.3 , and 0.5 to $1.5 \mathrm{~kg} / \mathrm{d}$, respectively. Halasa et al. (2009), who used a referent SCC of 50,000 cells $/ \mathrm{mL}$, predicted milk losses of 0.2 to $0.7 \mathrm{~kg} / \mathrm{d}$ at $\mathrm{SCC}$ of 250,000 cells $/ \mathrm{mL}$. Greatest milk losses were estimated by Raubertas and Shock (1982) and Hand et al. (2012), who used the lowest referent SCC of 1 and 7,400 cells/mL, respectively. As the latter authors used the lowest referent SCC, they reported milk losses that were not considered losses by other authors. Future research is needed to determine the appropriate referent SCC to estimating milk losses for increased SCC.

Predicted decreases of DMI were relatively smaller than losses in milk yield and ECM and, thus, $\mathrm{FE}_{\mathrm{MY}}$ and $\mathrm{FE}_{\mathrm{ECM}}$ were also predicted to decrease with increasing SCC. At SCC of 250,000 cells/mL, a referent SCC of 1 , $7,400,50,000$, and 100,000 cells $/ \mathrm{mL}$ predicted an average $\mathrm{FE}_{\mathrm{MY}}$ loss of $0.14,0.09,0.04$, and $0.04 \mathrm{~kg}$ of milk/ $\mathrm{kg}$ of DMI, respectively. Energy-corrected milk and $\mathrm{FE}_{\mathrm{ECM}}$ showed similar patterns as milk yield and $\mathrm{FE}_{\mathrm{MY}}$, but differences were smaller. We did not find any published studies reporting the effect of SCC on DMI or FE.

The present study suggests that a cow with relatively high SCC $(250,000$ cells $/ \mathrm{mL})$, compared with a cow with a relatively low SCC $(50,000$ cells $/ \mathrm{mL})$, produces $1.6 \mathrm{~kg} / \mathrm{d}$ less milk, consumes $0.3 \mathrm{~kg} / \mathrm{d}$ less DMI, and produces $0.04 \mathrm{~kg}$ less milk per $\mathrm{kg}$ of DMI $\left(\mathrm{FE}_{\mathrm{MY}}\right)$. Consequently, we would expect that a cow with relatively low SCC $(50,000$ cells $/ \mathrm{mL})$ that produces $35 \mathrm{~kg}$ of milk/d with an $\mathrm{FE}_{\mathrm{MY}}$ of $1.55 \mathrm{~kg}$ of milk/ $\mathrm{kg}$ of DMI would consume $0.6 \mathrm{~kg}$ less DMI per day than a cow with relatively high SCC (250,000 cells/mL) producing the same amount of milk because of the lower $\mathrm{FE}_{\mathrm{MY}}$ due to increased SCC. Income over feed costs for the cow with relatively high SCC $(250,000$ cells $/ \mathrm{mL})$ would be $\$ 0.17$ less per day, assuming a milk price of $\$ 0.34 / \mathrm{kg}$ of milk (\$15.50/cwt) and feed costs of $\$ 0.26 / \mathrm{kg}$ of DM $(\$ 0.12 / \mathrm{lb}$ of $\mathrm{DM})$. As treatment of mastitis is costly and its effectiveness depends on many factors, such as pathogens, stage of lactation, and the duration of the infection (Sol et al., 1997; Sandgren et al., 2008; Royster and Wagner, 2015), future efforts should be focused on mastitis prevention.

Our findings also have environmental implications because the greater DMI and decreased $\mathrm{FE}$ of cows with relatively high $\operatorname{SCC}(250,000$ cells $/ \mathrm{mL})$ is very likely to result in increased enteric methane emissions (g/d) and methane emission intensity ( $\mathrm{g}$ of methane $/ \mathrm{kg}$ of milk), as the positive correlation between DMI and enteric methane emissions has been well documented (Hristov et al., 2013; Moraes et al., 2014; Niu et al., 2018). We estimated methane emissions using predicted DMI and the following equation reported by Hristov et al. $(2013): \mathrm{CH}_{4}(\mathrm{~g} / \mathrm{d})=2.54(\mathrm{SE}=4.89)+19.14(\mathrm{SE}$ $=0.42) \times$ DMI $(\mathrm{kg} / \mathrm{d})$. The expected difference in DMI between a cow with relatively high SCC $(250,000$ cells/ $\mathrm{mL})$ and a cow with relatively low SCC (50,000 cells/ $\mathrm{mL}$ ) in the above example would result in an extra 12

Table 3. Predicted losses (95\% CI) in milk ECM, DMI, feed efficiency for milk ( $\mathrm{FE}_{\mathrm{MY}}$ ), and feed efficiency for $\mathrm{ECM}\left(\mathrm{FE} \mathrm{ECM}_{\mathrm{E}}\right)$ with increasing SCC in dairy cows and different SCC

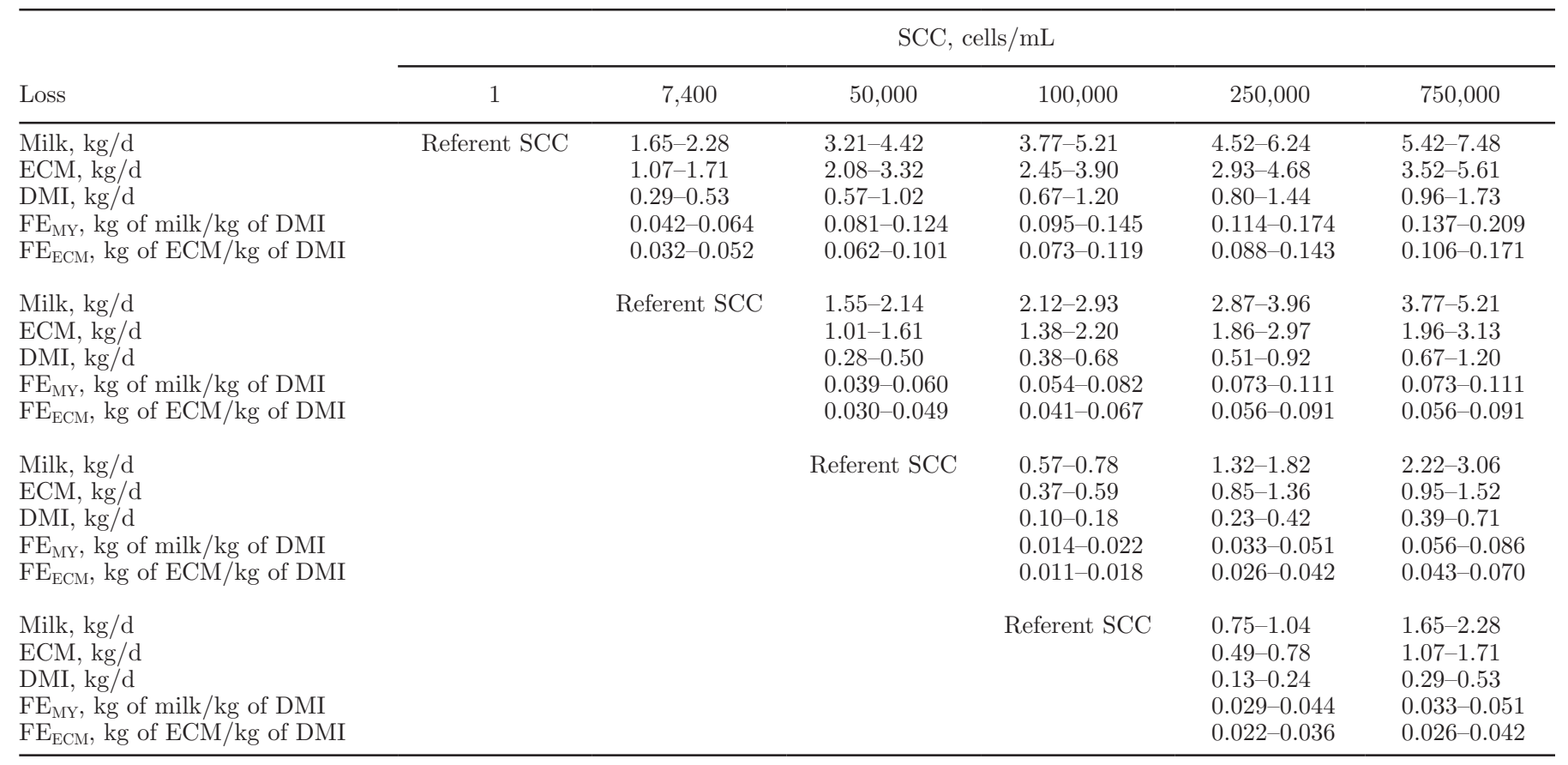


$\mathrm{g}$ of methane/d (or $4.4 \mathrm{~kg}$ of methane/yr, which is approximately $2.8 \%$ of the annual enteric methane emissions from a dairy cow in the United States; USEPA, 2017) and an extra $0.3 \mathrm{~g}$ of methane/ $\mathrm{kg}$ of milk $(2.8 \%$ more methane $/ \mathrm{kg}$ of milk).

This study showed that cows with relatively high SCC compared with cows with relatively low SCC produce less milk and have a lower DMI; however, reductions in milk are greater than reductions in DMI. Thus, cows with increased SCC compared with cows with relatively low SCC also have decreased FE. It is important to include FE losses in addition to milk losses when estimating the economic and environmental impacts of increased SCC and determining the economic viability of prevention and treatment of mastitis.

\section{ACKNOWLEDGMENTS}

T. Potter was supported by an internship with Environmental Defense Fund provided by The David R. and Patricia D. Atkinson Foundation. C. Arndt, and partially A. N. Hristov, were funded by a gift from Sue and Steve Mandel and the Kravis Scientific Research Fund provided to the Environmental Defense Fund (San Francisco, CA). A. N. Hristov's work was also partially supported by the USDA National Institute of Food and Agriculture (Washington, DC) Federal Appropriations under Project PEN 04539 and Accession number 1000803.

\section{REFERENCES}

Arndt, C., J. M. Powell, M. J. Aguerre, P. M. Crump, and M. A. Wattiaux. 2015. Feed conversion efficiency in dairy cows: Repeatability, variation in digestion and metabolism of energy and nitrogen, and ruminal methanogens. J. Dairy Sci. 98:3938-3950. https://doi .org/10.3168/jds.2014-8449.

Ballou, M. A. 2012. Growth and development symposium: Inflammation: Role in the etiology and pathophysiology of clinical mastitis in dairy cows. J. Anim. Sci. 90:1466-1478. https://doi.org/10 $.2527 /$ jas.2011-4663.

Bartlett, P. C., J. Van Wijk, D. J. Wilson, C. D. Green, G. Y. Miller, G. A. Majewski, and L. E. Heider. 1991. Temporal patterns of lost milk production following clinical mastitis in a large Michigan Holstein herd. J. Dairy Sci. 74:1561-1572. https://doi.org/10.3168/jds .S0022-0302(91)78318-5.

Bates, D., M. Maechler, B. Bolker, and S. Walker. 2015. Fitting linear mixed-effects models using lme4. J. Stat. Softw. 67:1-48. https:// doi.org/10.18637/jss.v067.i01.

Bauman, D. E., S. N. McCutcheon, W. D. Steinhour, P. J. Eppard, and S. J. Sechen. 1985. Sources of variation and prospects for improvement of productive efficiency in the dairy cow: A review. J. Anim. Sci. 60:583-592. https://doi.org/10.2527/jas1985.602583x.

Cha, E., D. Bar, J. A. Hertl, L. W. Tauer, G. Bennett, R. N. González, Y. H. Schukken, F. L. Welcome, and Y. T. Gröhn. 2011. The cost and management of different types of clinical mastitis in dairy cows estimated by dynamic programming. J. Dairy Sci. 94:44764487. https://doi.org/10.3168/jds.2010-4123.

Dürr, J. W., R. I. Cue, H. G. Monardes, J. Moro-Méndez, and K. M. Wade. 2008. Milk losses associated with somatic cell counts per breed, parity and stage of lactation in Canadian dairy cattle. Livest. Sci. 117:225-232. https://doi.org/10.1016/j.livsci.2007.12.004.

Giallongo, F., M. T. Harper, J. Oh, J. C. Lopes, H. Lapierre, R. A. Patton, C. Parys, I. Shinzato, and A. N. Hristov. 2016. Effects of rumen-protected methionine, lysine, and histidine on lactation performance of dairy cows. J. Dairy Sci. 99:4437-4452. https://doi .org/10.3168/jds.2015-10822.

Giallongo, F., M. T. Harper, J. Oh, C. Parys, I. Shinzato, and A. N. Hristov. 2017. Histidine deficiency has a negative effect on lactational performance of dairy cows. J. Dairy Sci. 100:2784-2800. https://doi.org/10.3168/jds.2016-11992.

Giallongo, F., A. N. Hristov, J. Oh, T. Frederick, H. Weeks, J. Werner, H. Lapierre, R. A. Patton, A. Gehman, and C. Parys. 2015. Effects of slow-release urea and rumen-protected methionine and histidine on performance of dairy cows. J. Dairy Sci. 98:3292-3308. https:/ /doi.org/10.3168/jds.2014-8791.

Godfray, H. C. J., J. R. Beddington, I. R. Crute, L. Haddad, D. Lawrence, J. F. Muir, J. Pretty, S. Robinson, S. M. Thomas, and C. Toulmin. 2010. Food security: The challenge of feeding 9 billion people. Science 327:812-818. https://doi.org/10.1126/science .1185383 .

Halasa, T., M. Nielen, A. P. W. De Roos, R. Van Hoorne, G. de Jong, T. J. G. M. Lam, T. van Werven, and H. Hogeveen. 2009. Production loss due to new subclinical mastitis in Dutch dairy cows estimated with a test-day model. J. Dairy Sci. 92:599-606. https:/ /doi.org/10.3168/jds.2008-1564.

Hand, K. J., A. Godkin, and D. F. Kelton. 2012. Milk production and somatic cell counts: A cow-level analysis. J. Dairy Sci. 95:1358 1362. https://doi.org/10.3168/jds.2011-4927.

Hortet, P., F. Beaudeau, H. Seegers, and C. Fourichon. 1999. Reduction in milk yield associated with somatic cell counts up to 600000 cells/ml in French Holstein cows without clinical mastitis. Livest. Prod. Sci. 61:33-42. https://doi.org/10.1016/S0301-6226(99)00051 -2 .

Hortet, P., and H. Seegers. 1998. Loss in milk yield and related composition changes resulting from clinical mastitis in dairy cows. Prev. Vet. Med. 37:1-20. https://doi.org/10.1016/S0167-5877(98)00104 -4 .

Hristov, A., J. Oh, C. Lee, R. Meinen, F. Montes, T. Ott, J. Firkins, A. Rotz, C. Dell, and A. Adesogan. 2013. Mitigation of Greenhouse Gas Emissions in Livestock Production: A Review of technical options for Non-CO2 Emissions. Food and Agriculture Organization of the United Nations, Rome, Italy.

Hristov, A. N., J. Oh, F. Giallongo, T. W. Frederick, M. T. Harper, H. L. Weeks, A. F. Branco, P. J. Moate, M. H. Deighton, S. R. Williams, M. Kindermann, and S. Duval. 2015. An inhibitor persistently decreased enteric methane emission from dairy cows with no negative effect on milk production. Proc. Natl. Acad. Sci. USA 112:10663-10668. https://doi.org/10.1073/pnas.1504124112.

Lee, C., A. N. Hristov, T. W. Cassidy, K. S. Heyler, H. Lapierre, G. A. Varga, M. J. De Veth, R. A. Patton, and C. Parys. 2012a. Rumenprotected lysine, methionine, and histidine increase milk protein yield in dairy cows fed a metabolizable protein-deficient diet. J. Dairy Sci. 95:6042-6056. https://doi.org/10.3168/jds.2012-5581.

Lee, C., A. N. Hristov, K. S. Heyler, T. W. Cassidy, H. Lapierre, G. A. Varga, and C. Parys. 2012b. Effects of metabolizable protein supply and amino acid supplementation on nitrogen utilization, milk production, and ammonia emissions from manure in dairy cows. J. Dairy Sci. 95:5253-5268. https://doi.org/10.3168/jds.2012-5366.

Lee, C., A. N. Hristov, K. S. Heyler, T. W. Cassidy, M. Long, B. A. Corl, and S. K. R. Karnati. 2011. Effects of dietary protein concentration and coconut oil supplementation on nitrogen utilization and production in dairy cows. J. Dairy Sci. 94:5544-5557. https:/ /doi.org/10.3168/jds.2010-3889.

Leslie, K. E., and C. S. Petersson-Wolfe. 2012. Assessment and management of pain in dairy cows with clinical mastitis. Vet. Clin. North Am. Food Anim. Pract. 28:289-305. https://doi.org/10 .1016/j.cvfa.2012.04.002.

Moraes, L. E., A. B. Strathe, J. G. Fadel, D. P. Casper, and E. Kebreab. 2014. Prediction of enteric methane emissions from cattle. 
Glob. Chang. Biol. 20:2140-2148. https://doi.org/10.1111/gcb .12471.

Niu, M., E. Kebreab, A. N. Hristov, J. Oh, C. Arndt, A. Bannink, A. R. Bayat, A. F. Brito, T. Boland, D. Casper, L. A. Crompton, J. Dijkstra, M. A. Eugène, P. C. Garnsworthy, M. N. Haque, A. L. F. Hellwing, P. Huhtanen, M. Kreuzer, B. Kuhla, P. Lund, J. Madsen, C. Martin, S. C. Mcclelland, M. Mcgee, P. J. Moate, S. Muetzel, C. Muñoz, P. O'kiely, N. Peiren, C. K. Reynolds, A. Schwarm, K. J. Shingfield, T.M. Storlien, M. R. Weisbjerg, D. R. Yáñez-Ruiz, and Z. Yu. 2018. Prediction of enteric methane production, yield, and intensity in dairy cattle using an intercontinental database. Glob. Chang. Biol. https://doi.org/10.1111/gcb.14094.

Raubertas, R. F., and G. E. Shook. 1982. Relationship between lactation measures of somatic cell concentration and milk yield. J. Dairy Sci. 65:419-425. https://doi.org/10.3168/jds.S0022-0302(82)82207 -8 .

Rollin, E., K. C. Dhuyvetter, and M. W. Overton. 2015. The cost of clinical mastitis in the first 30 days of lactation: An economic modeling tool. Prev. Vet. Med. 122:257-264. https://doi.org/10.1016/j .prevetmed.2015.11.006.

Royster, E., and S. Wagner. 2015. Treatment of mastitis in cattle. Vet. Clin. North Am. Food Anim. Pract. 31:17-46. https://doi.org/10 .1016/j.cvfa.2014.11.010.
Sandgren, C. H., K. P. Waller, and U. Emanuelson. 2008. Therapeutic effects of systemic or intramammary antimicrobial treatment of bovine subclinical mastitis during lactation. Vet. J. 175:108-117. https://doi.org/10.1016/j.tvjl.2006.12.005.

Sol, J., O. C. Sampimon, J. J. Snoep, and Y. H. Schukken. 1997. Factors associated with bacteriological cure during lactation after therapy for subclinical mastitis caused by staphylococcus aureus. J. Dairy Sci. 80:2803-2808. https://doi.org/10.3168/jds.S0022 -0302(97)76243-X.

USEPA. 2017. Inventory of U.S. greenhouse gases and sinks: 19902015. USEPA, Washington, DC, April 2017. Accessed September 2017. https://www.epa.gov/sites/production/files/2017-02/ documents/2017_complete_report.pdf.

VandeHaar, M. J., L. E. Armentano, K. Weigel, D. M. Spurlock, R. J. Tempelman, and R. Veerkamp. 2016. Harnessing the genetics of the modern dairy cow to continue improvements in feed efficiency. J. Dairy Sci. 99:4941-4954. https://doi.org/10.3168/jds $.2015-10352$. 